\title{
СТАНОВЛЕНИЕ И РАЗВИТИЕ ГОСУДАРСТВЕННОЙ АГРАРНОЙ ПОЛИТИКИ: СРАВНИТЕЛЬНЫЙ ИНДИКАТИВНЫЙ АНАЛИЗ
}

\begin{abstract}
Аннотация: $B$ статье проведен сравнительный анализ политики, права, аграрной политики и аграрного права в их взаимосвязи. Это позволяет увидеть общее и особенное в этих явлениях действительности, а такље установить индикаторы сравнения и основы взаимодействия. Анализ выявляет специфику агрополитического пространства и агрополитического воздействия на аграрное производство и свидетельствует о внутреннем родстве аграрной экономики и аграрной политики государства; создает почву для более глубокого познания названной политики.
\end{abstract}

Ключевые слова: государство, право, аграрная политика, сравнительныцй индикативный анализ, агрополитическое воздействие.

$\mathrm{K}$ атегория «политика», рассмотренная в самом широком смысле, представляет собой наиболее общее логическое понятие, выражающее одну из основных форм бытия или одно из его основных отношений (материя, сущность, пространство, время, движение, причинность и т.д.). В таком качестве она является принадлежностью мироздания - самой сложной и сложнейшей субстанции такой, как реальная действительность. Сложный характер первоосновы предполагает процессность, последовательную смену состояний ее развития, становления и бытия, тесную связь закономерно следующих друг за другом стадий присутствия и проявления и, как следствие этого, требует анализа особенностей данного феномена с позиций причин возникновения (AB INITIO), продвижения, прохождения в рамках единства природного (пространства и времени) и разумного, осознания и познания рационального (целесообразного), естественного и духовного, объективного и субъективного, с точки зрения оценки результативности функционирования, теоретического и практического, общественного и государственного компонентов, непрерывно взаимодействующих в пределах целого (общества). Общество есть результат имманентно сформированной и интегрированной материальными условиями жизни совокупности связей, нуждающейся, в свою очередь, в собственной ар- хитектонике, сложной многоуровневой структуре, в системности и целесообразной реакции на внешние и внутренние факторы в виде социального воздействия и саморегулирования, в оправданном и рациональном поведении, социальных акциях, направленных на сохранение и развитие целостности. Естественное начало, таким образом, инициирует позитивное отношение к происходящему, адаптирует общество к природной среде, материализует его, «вводя» в число социальных предпосылок становления и бытия всего сущего, в том числе и деятельности, называемой политикой. Как указывалось ранее, квинтессенцию аграрной политики предопределяет объективный и независимый от человеческой воли и сознания закон саморегуляции (саморазвития) природы в его общественном преломлении ${ }^{1}$ (см. нижеприведенную таблицу). Ниже в таблице приведен сравнительный индикативный анализ таких взаимосвязанных взаимопроникающих явлений, как политика, право, аграрная политика и аграрное право. Данный анализ позволяет увидеть общее и особенное в этих явлениях, а также установить основы (индикаторы) их взаимодействия.

\footnotetext{
${ }^{1}$ Ханнанов Р.А., Ханнанова Т.P. События в системе правового обеспечения модернизации социально-экономического развития России: теория и практика. - Уфа.: Башкирский ГАУ, АН РБ, 2012. - 162 с. - С. 17-35, 65-95, 97-106.
} 


\begin{tabular}{|c|c|c|c|c|c|}
\hline $\begin{array}{l}\text { № } \\
\Pi / \Pi\end{array}$ & $\begin{array}{c}\text { Индика- } \\
\text { торы (по- } \\
\text { казатели) } \\
\text { признаков, } \\
\text { свойств }\end{array}$ & Политика & Право & Аграрная политика & Аграрное право \\
\hline 1 & 2 & 3 & 4 & 5 & 6 \\
\hline 1. & $\begin{array}{l}\text { Предпосыл- } \\
\text { ки станов- } \\
\text { ления (фор- } \\
\text { мирования, } \\
\text { зарожде- } \\
\text { ния, об- } \\
\text { разования, } \\
\text { возникнове- } \\
\text { ния) и бы- } \\
\text { тия (суще- } \\
\text { ствования, } \\
\text { развития) }\end{array}$ & $\begin{array}{l}\text { Всеобщий, объектив- } \\
\text { ный, универсальный } \\
\text { закон саморегуляции } \\
\text { (саморазвития) приро- } \\
\text { ды в преломлении оду- } \\
\text { хотворенного состоя- } \\
\text { ния (в дальнейшем для } \\
\text { краткости обозначения } \\
\text { - закон природы) }\end{array}$ & $\begin{array}{l}\text { Обусловленные за- } \\
\text { коном природы три } \\
\text { крупные обществен- } \\
\text { ные разделения труда } \\
\text { (отделение ремесла от } \\
\text { земледелия, отделение } \\
\text { пастушеских племен } \\
\text { от земледелия, появ- } \\
\text { ление класса купцов), } \\
\text { приведшие к воз- } \\
\text { никновению частной } \\
\text { собственности, расколу } \\
\text { общества на классы с } \\
\text { антогоническими инте- } \\
\text { ресами, а также появ- } \\
\text { лению государства }\end{array}$ & $\begin{array}{l}\text { Обусловленная дей- } \\
\text { ствием закона при- } \\
\text { роды, сложившаяся } \\
\text { веками стабильная } \\
\text { отсталость сель- } \\
\text { скохозяйственного } \\
\text { производства, огра- } \\
\text { ниченность биоре- } \\
\text { сурсов и вызванные } \\
\text { ими общественные } \\
\text { потребности в по- } \\
\text { ступательном раз- } \\
\text { витии аграрного } \\
\text { сектора экономики }\end{array}$ & $\begin{array}{l}\text { Объективная не- } \\
\text { обходимость в } \\
\text { правовом обеспе- } \\
\text { чении аграрного } \\
\text { производства и спо- } \\
\text { собствовании даль- } \\
\text { нейшему прогрессу } \\
\text { агрохозяйственной } \\
\text { деятельности в ре- } \\
\text { жиме его устойчи- } \\
\text { вости и эффектив- } \\
\text { ности }\end{array}$ \\
\hline 2 . & $\begin{array}{l}\text { Естествен- } \\
\text { ные основы } \\
\text { возникнове- } \\
\text { ния в каче- } \\
\text { стве соци- } \\
\text { альной на- } \\
\text { личности, } \\
\text { элемента } \\
\text { социальной } \\
\text { реальности }\end{array}$ & $\begin{array}{l}\text { Предопределенное } \\
\text { законом природы са- } \\
\text { моразвитие в его кон- } \\
\text { кретных проявлениях, } \\
\text { материализация его } \\
\text { до уровня качествен- } \\
\text { ного состояния со- } \\
\text { циальной реальности } \\
\text { в виде особых связей } \\
\text { - политических от- } \\
\text { ношений, обладающих } \\
\text { статусом объективной } \\
\text { данности, возникаю- } \\
\text { щих изначально (АВ } \\
\text { INCUNABULIS, IN } \\
\text { INITIO) и существу- } \\
\text { ющих во все периоды } \\
\text { функционирования } \\
\text { человеческого обще- } \\
\text { ства независимо от } \\
\text { субъективного мне- } \\
\text { ния и усмотрения (А } \\
\text { DESCRETION) }\end{array}$ & $\begin{array}{l}\text { Проявления закона } \\
\text { природы (его законо- } \\
\text { мерностей) в области } \\
\text { функционирования } \\
\text { общественной практи- } \\
\text { ки и общественного со- } \\
\text { знания, сформирован- } \\
\text { ных тысячелетиями, } \\
\text { прошедших испытание } \\
\text { временем и ставшим } \\
\text { объективными и тре- } \\
\text { бующими познания, } \\
\text { признания в виде спец- } \\
\text { ифических социальных } \\
\text { реальностей - правосо- } \\
\text { знания, права }\end{array}$ & $\begin{array}{l}\text { Проявление законо- } \\
\text { мерностей закона } \\
\text { природы в области } \\
\text { агро-хозяйственной } \\
\text { деятельности и вос- } \\
\text { приятия их в каче- } \\
\text { стве объективно об- } \\
\text { условленной соци- } \\
\text { альной реальности } \\
\text { в аграрном секторе } \\
\text { (DE FACTO) }\end{array}$ & $\begin{array}{l}\text { Объективно су- } \\
\text { ществующая не- } \\
\text { обходимость в } \\
\text { способствовании } \\
\text { позитивно резуль- } \\
\text { тативному, вос- } \\
\text { производственному } \\
\text { режиму агрохозяй- } \\
\text { ственной деятель- } \\
\text { ности, проявлению } \\
\text { его саморегулятив- } \\
\text { ных возможностей }\end{array}$ \\
\hline
\end{tabular}




\section{Политика и общество 3 (99) • 2013}

\begin{tabular}{|c|c|c|c|c|c|}
\hline 3. & $\begin{array}{l}\text { Формали- } \\
\text { зация есте- } \\
\text { ственных } \\
\text { основ }\end{array}$ & $\begin{array}{l}\text { Природные, объектив- } \\
\text { но происходящие и } \\
\text { независимые от воли } \\
\text { участников обще- } \\
\text { ственных отношений } \\
\text { обстоятельства, есте- } \\
\text { ственные события (AU } \\
\text { NATUREL) }\end{array}$ & $\begin{array}{l}\text { Естественные и соци- } \\
\text { альные, органически } \\
\text { связанные, взаимодей- } \\
\text { ствующие, трансфор- } \\
\text { мирующиеся из при- } \\
\text { родной разновидности } \\
\text { бытия в социальную } \\
\text { сферу функционирова- } \\
\text { ния и, наоборот, пере- } \\
\text { ходящие из идеальной } \\
\text { сферы в область внеш- } \\
\text { ней действительности, } \\
\text { объективные обстоя- } \\
\text { тельства, события }\end{array}$ & $\begin{array}{l}\text { Предопределенные } \\
\text { природой биопро- } \\
\text { извод-ственные } \\
\text { обстоятельства, со- } \\
\text { бытия }\end{array}$ & $\begin{array}{l}\text { Естественные и } \\
\text { приобретенные } \\
\text { свойства объектив- } \\
\text { ности, социальные } \\
\text { обстоятельства, } \\
\text { события, признава- } \\
\text { емые юридически- } \\
\text { ми фактами (ст. } 8 \\
\text { ГК РФ, Закон РФ о } \\
\text { развитии сельского } \\
\text { хозяйства и другие } \\
\text { законы РФ и ее } \\
\text { субъектов) }\end{array}$ \\
\hline 4. & $\begin{array}{l}\text { Духовные } \\
\text { основы } \\
\text { формирова- } \\
\text { ния в виде } \\
\text { элемента } \\
\text { социальной } \\
\text { реальности }\end{array}$ & $\begin{array}{l}\text { Совокупность идей и } \\
\text { методов сознательного } \\
\text { саморегулирования об- } \\
\text { щества и отношений, } \\
\text { возникающих в про- } \\
\text { цессе их реализации }\end{array}$ & $\begin{array}{l}\text { Концептно-концепту- } \\
\text { альные и другие идео- } \\
\text { логического характера } \\
\text { институты, предназна- } \\
\text { ченные для правового } \\
\text { регулирования обще- } \\
\text { ственных отношений }\end{array}$ & $\begin{array}{l}\text { Совокупность идей } \\
\text { и методов осознан- } \\
\text { ного регулирования } \\
\text { агрохозяй-ственных } \\
\text { отношений, над- } \\
\text { лежащего обеспече- } \\
\text { ния устойчивости } \\
\text { и эффективности } \\
\text { аграрного произ- } \\
\text { водства }\end{array}$ & $\begin{array}{l}\text { Претворение в } \\
\text { жизнь идеологии } \\
\text { правовой органи- } \\
\text { зации аграрного } \\
\text { производства, } \\
\text { осуществления его } \\
\text { на стабильной и до- } \\
\text { ходной основе }\end{array}$ \\
\hline 5. & $\begin{array}{l}\text { Формализа- } \\
\text { ция духов- } \\
\text { ных основ }\end{array}$ & $\begin{array}{l}\text { Результаты научных } \\
\text { исследований проблем } \\
\text { развития общества в } \\
\text { виде разработок и ре- } \\
\text { комендаций }\end{array}$ & $\begin{array}{l}\text { Предложения по со- } \\
\text { вершенствованию и } \\
\text { обновлению норматив- } \\
\text { но-правовых актов }\end{array}$ & $\begin{array}{l}\text { Результаты научных } \\
\text { исследований и } \\
\text { передовой практики } \\
\text { хозяйствования на } \\
\text { селе в виде разрабо- } \\
\text { ток и рекомендаций }\end{array}$ & $\begin{array}{l}\text { Юридические } \\
\text { акты, предусмо- } \\
\text { тренные нормами } \\
\text { аграрноправовых } \\
\text { актов всех уровней } \\
\text { власти, управления, } \\
\text { товаропроизводи- } \\
\text { телей }\end{array}$ \\
\hline 6. & $\begin{array}{l}\text { Целепола- } \\
\text { гание }\end{array}$ & $\begin{array}{l}\text { Реальный или идеаль- } \\
\text { ный предмет в виде } \\
\text { финального результата } \\
\text { развития связей по } \\
\text { поводу устройства и } \\
\text { управления обществом }\end{array}$ & $\begin{array}{l}\text { Достижение закон- } \\
\text { ности - своеобразного } \\
\text { политико-правового } \\
\text { режима общественной } \\
\text { жизни и правового по- } \\
\text { рядка, отражающего } \\
\text { итог воплощения за- } \\
\text { конности в реальные } \\
\text { общественные отно- } \\
\text { шения }\end{array}$ & $\begin{array}{l}\text { Достижение субъ- } \\
\text { ектами агрохозяй- } \\
\text { ственных отноше- } \\
\text { ний устойчивости } \\
\text { и эффективности } \\
\text { аграрного произ- } \\
\text { водства }\end{array}$ & $\begin{array}{l}\text { Правовое обеспе- } \\
\text { чение требований } \\
\text { норм аграрного } \\
\text { права в сфере } \\
\text { организации и ве- } \\
\text { дения аграрного } \\
\text { производства и со- } \\
\text { блюдения государ- } \\
\text { ственной аграрной } \\
\text { дисциплины }\end{array}$ \\
\hline 7. & Задачи & $\begin{array}{l}\text { Организация и осу- } \\
\text { ществление руководя- } \\
\text { щей, направляющей, а } \\
\text { также }\end{array}$ & $\begin{array}{l}\text { Высший надзор за } \\
\text { соблюдением закон- } \\
\text { ности и правопорядка } \\
\text { в стране }\end{array}$ & $\begin{array}{l}\text { Политическая } \\
\text { организация всех } \\
\text { участников агрохо- } \\
\text { зяйственного про- } \\
\text { цесса, }\end{array}$ & $\begin{array}{l}\text { Обеспечение взаи- } \\
\text { мосвязи между по- } \\
\text { литическими } \\
\text { и правовыми }\end{array}$ \\
\hline
\end{tabular}


Государство и гражданское общество

\begin{tabular}{|c|c|c|c|c|c|}
\hline & & $\begin{array}{l}\text { координационной } \\
\text { (CO(N)+ORDINATIO) } \\
\text { деятельности между } \\
\text { людьми и организа- } \\
\text { циями, между ними } \\
\text { и государством по } \\
\text { реализации их общих } \\
\text { интересов }\end{array}$ & & $\begin{array}{l}\text { направленная на } \\
\text { устойчивое и эф- } \\
\text { фективное развитие } \\
\text { аграрного произ- } \\
\text { водства и аграрного } \\
\text { бизнеса, на повы- } \\
\text { шение жизненного } \\
\text { уровня населения и } \\
\text { достижение соци- } \\
\text { ального прогресса } \\
\text { на селе }\end{array}$ & $\begin{array}{l}\text { отношениями, } \\
\text { возникающими и } \\
\text { функционирующи- } \\
\text { ми в аграрном сек- } \\
\text { торе экономики }\end{array}$ \\
\hline 8. & $\begin{array}{l}\text { Простран- } \\
\text { ственное } \\
\text { выражение }\end{array}$ & $\begin{array}{l}\text { Политическое про- } \\
\text { странство, рефлек- } \\
\text { сивно (REFLEXIO) } \\
\text { и синтетически } \\
\text { (SYNTHESIS) выража- } \\
\text { ющее политическую } \\
\text { организацию общества } \\
\text { в единстве содержа- } \\
\text { ния и формы полити- } \\
\text { ческого процесса и } \\
\text { осознаваемое в форме } \\
\text { законов, отпечатков, } \\
\text { моделей, алгоритмов, } \\
\text { конструкций и других } \\
\text { образцов, реализуемое } \\
\text { в рамках ареала поли- } \\
\text { тического воздействия } \\
\text { на общественные от- } \\
\text { ношения }\end{array}$ & $\begin{array}{l}\text { Пространство действия } \\
\text { нормативных актов, } \\
\text { определяемое законо- } \\
\text { дателем при введении } \\
\text { нормативных актов в } \\
\text { действие (федерация, } \\
\text { субъекты федерации, } \\
\text { муниципальные обра- } \\
\text { зования) }\end{array}$ & $\begin{array}{l}\text { Социально-эконо- } \\
\text { мическая система, } \\
\text { размещаемая по } \\
\text { особым политиче- } \\
\text { ским осям и ареалам } \\
\text { функционирования } \\
\text { агрохозяйственных } \\
\text { формирований (от- } \\
\text { раслей, подотрас- } \\
\text { лей, производствен- } \\
\text { ных объединений и } \\
\text { союзов, кластеров, } \\
\text { агломераций и т.д.), } \\
\text { а также усмотрению } \\
\text { субъектов полити- } \\
\text { ческой деятельно- } \\
\text { сти, выражающая } \\
\text { и воплощающаяся } \\
\text { в общеизвестных } \\
\text { принципах рыноч- } \\
\text { ного регулирования } \\
\text { аграрной экономики } \\
\text { (пространство эко- } \\
\text { номических дей- } \\
\text { ствий; всеобщность } \\
\text { рынка; свободный } \\
\text { выбор видов и форм } \\
\text { деятельности; госу- } \\
\text { дарственное регули- } \\
\text { рование; свободное } \\
\text { ценообразование; } \\
\text { самофинансирова- } \\
\text { ние; конкуренция; } \\
\text { хозяйственная са- } \\
\text { мостоятельность; } \\
\text { децентрализация } \\
\text { управления и др.) }\end{array}$ & $\begin{array}{l}\text { Определяемое по- } \\
\text { средством призна- } \\
\text { ния и юридического } \\
\text { закрепления в нор- } \\
\text { мах актов аграрного } \\
\text { права }\end{array}$ \\
\hline
\end{tabular}


Политика и общество 3 (99) • 2013

\begin{tabular}{|c|c|c|c|c|c|}
\hline 9. & \begin{tabular}{l|} 
Социальное \\
познание \\
политиче- \\
ского про- \\
странства
\end{tabular} & $\begin{array}{l}\text { Создание условий для } \\
\text { адекватного иссле- } \\
\text { дования целостности } \\
\text { социальной системы } \\
\text { в политическом от- } \\
\text { ношении, воплощения } \\
\text { тенденции к синтети- } \\
\text { ческой подвижности } \\
\text { (государства, власти, } \\
\text { идеологии, элиты, по- } \\
\text { литические институ- } \\
\text { ты), осознания этой це- } \\
\text { лостности, выявления } \\
\text { в ней места каждого } \\
\text { элемента системы }\end{array}$ & $\begin{array}{l}\text { Правовое регулиро- } \\
\text { вание политических } \\
\text { отношений в рамках, } \\
\text { установленным зако- } \\
\text { ном, обеспечение спра- } \\
\text { ведливого соотноше- } \\
\text { ния между политикой } \\
\text { и правом, устранение } \\
\text { возникающих при этом } \\
\text { коллизий }\end{array}$ & $\begin{array}{l}\text { Адаптация общепо- } \\
\text { литических требо- } \\
\text { ваний к аграрному } \\
\text { сектору экономики, } \\
\text { политическое ре- } \\
\text { гулирование агро- } \\
\text { производственных } \\
\text { связей }\end{array}$ & $\begin{array}{l}\text { Правовое обеспе- } \\
\text { чение, размещение } \\
\text { и специализация } \\
\text { политического } \\
\text { процесса в особой } \\
\text { сфере деятельно- } \\
\text { сти политического } \\
\text { субъекта }\end{array}$ \\
\hline 10. & $\begin{array}{l}\text { Временные } \\
\text { границы } \\
\text { (пределы) }\end{array}$ & $\begin{array}{l}\text { Время, этап развития } \\
\text { политических отно- } \\
\text { шений, измеряемые } \\
\text { частотой событий в } \\
\text { единицу физического } \\
\text { времени, определяю- } \\
\text { щейся интенсивностью } \\
\text { деятельности полити- } \\
\text { ческого субъекта }\end{array}$ & $\begin{array}{l}\text { Время действия нор- } \\
\text { мативных актов, опре- } \\
\text { деляемое законом при } \\
\text { введении их в действие } \\
\text { с учетом длительности } \\
\text { и последовательности } \\
\text { взаимодействия субъ- } \\
\text { ектов и объектов по- } \\
\text { литики }\end{array}$ & $\begin{array}{l}\text { Время развития } \\
\text { политических отно- } \\
\text { шений в аграрном } \\
\text { секторе экономики, } \\
\text { определяемое с } \\
\text { учетом специфи- } \\
\text { ки регулирования } \\
\text { аграрных отноше- } \\
\text { ний, особенностей } \\
\text { сельскохозяйствен- } \\
\text { ного производства } \\
\text { (природных и ду- } \\
\text { ховных, ресурсных } \\
\text { и творческих и др.) }\end{array}$ & $\begin{array}{l}\text { Устанавливаемое } \\
\text { нормами аграр- } \\
\text { ного права время } \\
\text { осуществления } \\
\text { мероприятий агро- } \\
\text { политического ха- } \\
\text { рактера, агрохозяй- } \\
\text { ственного процесса }\end{array}$ \\
\hline 11. & $\begin{array}{l}\text { Социальное } \\
\text { назначение } \\
\text { политиче- } \\
\text { ского вре- } \\
\text { мени }\end{array}$ & $\begin{array}{l}\text { Определенные меры } \\
\text { событийной насыщен- } \\
\text { ности политического } \\
\text { процесса и содержания } \\
\text { на тех или иных этапах } \\
\text { его развития, свойства } \\
\text { многомерности, вклю- } \\
\text { чающей в себя мно- } \\
\text { жество возможностей, } \\
\text { направлений полити- } \\
\text { ческих действий, вы- } \\
\text { званных спецификой } \\
\text { социальной закономер- } \\
\text { ности, разными темпа- } \\
\text { ми развития общества }\end{array}$ & $\begin{array}{l}\text { Правовое обеспечение } \\
\text { стабильности поли- } \\
\text { тических отношений, } \\
\text { способствование } \\
\text { их утверждению и } \\
\text { функционированию в } \\
\text { опережающем темпе в } \\
\text { интересах достижения } \\
\text { социально значимых } \\
\text { целей развития обще- } \\
\text { ства (роста числа обо- } \\
\text { стрений политической } \\
\text { жизни, повышения } \\
\text { степени социальной и } \\
\text { психологической на- } \\
\text { пряженности, резкого } \\
\text { наступления политиче- } \\
\text { ских перемен и т.п.) }\end{array}$ & $\begin{array}{l}\text { Восприятие оправ- } \\
\text { давших себя мер } \\
\text { политического } \\
\text { характера и со- } \\
\text { держания в ключе } \\
\text { разновременной } \\
\text { предопределенно- } \\
\text { сти и многомерно- } \\
\text { сти возможностей, } \\
\text { возникающих (тая- } \\
\text { щихся) в аграрной } \\
\text { сфере экономики }\end{array}$ & $\begin{array}{l}\text { Правовое обеспече- } \\
\text { ние своевременного } \\
\text { осуществления } \\
\text { политического про- } \\
\text { цесса в сельском } \\
\text { хозяйстве и АПК }\end{array}$ \\
\hline
\end{tabular}


Государство и гражданское общество

\begin{tabular}{|c|c|c|c|c|c|}
\hline 12. & $\begin{array}{l}\text { Систем- } \\
\text { ность фор- } \\
\text { мирования } \\
\text { и функцио- } \\
\text { нирования }\end{array}$ & $\begin{array}{l}\text { Возникающее на ра- } \\
\text { циональной основе } \\
\text { (лидерство, органы вла- } \\
\text { сти, регламентация) об- } \\
\text { ладающее признаками, } \\
\text { характеризующими си- } \\
\text { стему (целостностью и } \\
\text { единством), вытекающее } \\
\text { из природы политики и } \\
\text { власти образование, пре- } \\
\text { следующее в силу зани- } \\
\text { маемого специфического } \\
\text { положения в обществе } \\
\text { и осуществляющее ини- } \\
\text { циативу ради и для до- } \\
\text { стижения поставленной } \\
\text { цели посредством при- } \\
\text { влечения человеческого } \\
\text { сообщества }\end{array}$ & $\begin{array}{l}\text { Создаваемая право- } \\
\text { творческими органами } \\
\text { государства сово- } \\
\text { купность предметно } \\
\text { определенных и рас- } \\
\text { пределенных по субин- } \\
\text { ститутам, институтам, } \\
\text { отраслям и подотрас- } \\
\text { лям права правил пове- } \\
\text { дения, регулирующая } \\
\text { социально-экономиче- } \\
\text { ские отношения }\end{array}$ & $\begin{array}{l}\text { Объективно об- } \\
\text { условленная и } \\
\text { концептно-концеп- } \\
\text { туальная, предна- } \\
\text { чертанная совокуп- } \\
\text { ность принципов и } \\
\text { способов государ- } \\
\text { ственного воздей- } \\
\text { ствия на аграрную } \\
\text { экономику, на раз- } \\
\text { витие сельской ин- } \\
\text { фраструктуры, обе- } \\
\text { спечение политиче- } \\
\text { ской стабильности } \\
\text { и продовольствен- } \\
\text { ной безопасности и } \\
\text { независимости }\end{array}$ & $\begin{array}{l}\text { Система норм } \\
\text { аграрного права, } \\
\text { предназначенная } \\
\text { для правового обе- } \\
\text { спечения аграрной } \\
\text { политики государ- } \\
\text { ства }\end{array}$ \\
\hline 13. & $\begin{array}{l}\text { Область } \\
\text { бытия }\end{array}$ & $\begin{array}{l}\text { Сфера отношений между } \\
\text { социальными, интегри- } \\
\text { рованными материаль- } \\
\text { ными условиями жизни, } \\
\text { сообществами (классами, } \\
\text { нациями, народностями, } \\
\text { партиями, общественны- } \\
\text { ми организациями, граж- } \\
\text { данами и др.) по поводу } \\
\text { государственной власти } \\
\text { и государственного } \\
\text { устройства внутри дан- } \\
\text { ного общества и прояв- } \\
\text { ления процесса действия } \\
\text { субъектов политической } \\
\text { системы }\end{array}$ & $\begin{array}{l}\text { Сфера отношений по } \\
\text { правотворчеству и } \\
\text { правоприменению, раз- } \\
\text { вивающихся в рамках } \\
\text { политического про- } \\
\text { странства и времени }\end{array}$ & $\begin{array}{l}\text { Сфера отношений } \\
\text { политического } \\
\text { (государственно- } \\
\text { го) воздействия на } \\
\text { аграрное и агропро- } \\
\text { мышленное произ- } \\
\text { водство }\end{array}$ & $\begin{array}{l}\text { Сфера создания и } \\
\text { функционирования } \\
\text { норм аграрного } \\
\text { права, использова- } \\
\text { ния их совместно с } \\
\text { политико-обуслов- } \\
\text { ленными правила- } \\
\text { ми в регулировании } \\
\text { агрохозяйственных } \\
\text { отношений }\end{array}$ \\
\hline 14. & $\begin{array}{l}\text { Системная } \\
\text { объектива- } \\
\text { ция в со- } \\
\text { циальной } \\
\text { среде }\end{array}$ & $\begin{array}{l}\text { Формирование в виде } \\
\text { единого целостного об- } \\
\text { разования, закономер- } \\
\text { но функционирующего } \\
\text { в качестве относитель- } \\
\text { но самостоятельного } \\
\text { элемента политической } \\
\text { системы, включающего } \\
\text { ряд социальных инсти- } \\
\text { тутов, определяющих } \\
\text { место и роль, }\end{array}$ & $\begin{array}{l}\text { Научно разработанная } \\
\text { и юридически при- } \\
\text { знанная система права } \\
\text { государства }\end{array}$ & $\begin{array}{l}\text { Формирование } \\
\text { в виде особой, } \\
\text { специфической со- } \\
\text { ставляющей эконо- } \\
\text { мической системы } \\
\text { хозяйства, подвер- } \\
\text { гаемой автономно- } \\
\text { му, характерному } \\
\text { для агрохозяйствен- } \\
\text { ной деятельности, } \\
\text { политическому воз- } \\
\text { действию и регули- } \\
\text { рованию }\end{array}$ & $\begin{array}{l}\text { Опирающаяся на } \\
\text { нормы комплексной } \\
\text { отрасли аграрного } \\
\text { права регламентация } \\
\text { агрохозяйственных } \\
\text { отношений как по- } \\
\text { литически предопре- } \\
\text { деленных объектов } \\
\text { (способов и мето- } \\
\text { дов) регулирования } \\
\text { аграрной деятель- } \\
\text { ности, а также на } \\
\text { положения актов }\end{array}$ \\
\hline
\end{tabular}




\section{Политика и общество 3 (99) • 2013}

\begin{tabular}{|c|c|c|c|c|c|}
\hline & & $\begin{array}{l}\text { а также структуру сво- } \\
\text { их связей и функций, } \\
\text { возможные пределы } \\
\text { легитимации и регу- } \\
\text { лирования этих связей } \\
\text { особыми нормами } \\
\text { - политическими и } \\
\text { правовыми }\end{array}$ & & & $\begin{array}{l}\text { индивидуально- } \\
\text { правового характера } \\
\text { (актов применения } \\
\text { права: договоры, од- } \\
\text { носторонние сделки, } \\
\text { административные } \\
\text { акты, юридические } \\
\text { поступки, обычаи } \\
\text { делового оборота и } \\
\text { т.д. Ст. } 8 \text { ГК РФ) }\end{array}$ \\
\hline 15. & $\begin{array}{l}\text { Компози- } \\
\text { ционность } \\
\text { структуры } \\
\text { системы }\end{array}$ & $\begin{array}{l}\text { Включенность в меха- } \\
\text { низм функционирования } \\
\text { политической системы, } \\
\text { в общий комплекс со- } \\
\text { циальных систем, с } \\
\text { одной стороны, и в свою } \\
\text { специфическую, отража- } \\
\text { ющую собственный об- } \\
\text { лик, опредмечивающий } \\
\text { политические идеи в } \\
\text { проекты, систему, с дру- } \\
\text { гой стороны (социальная } \\
\text { политизация, форми- } \\
\text { рование политического } \\
\text { сознания у субъектов по- } \\
\text { литических отношений; } \\
\text { политическая организа- } \\
\text { ция общества; коммуни- } \\
\text { кативность, информаци- } \\
\text { онность политической } \\
\text { власти , политической } \\
\text { системы и общества; } \\
\text { нормативность регули- } \\
\text { рования политической } \\
\text { жизни; политическая } \\
\text { практика; способы обе- } \\
\text { спечения политической } \\
\text { власти: интеграция об- } \\
\text { щества и создание усло- } \\
\text { вий для взаимодействия } \\
\text { различных элементов } \\
\text { структуры; мобилизация } \\
\text { ресурсов для достижения } \\
\text { целей и задач; выявление, } \\
\text { представительство, удов- } \\
\text { летворение интересов } \\
\text { субъектов политических } \\
\text { отношений и т.д.) }\end{array}$ & $\begin{array}{l}\text { Распределенность пра- } \\
\text { вовых норм, регулиру- } \\
\text { ющих политические } \\
\text { отношения по отдель- } \\
\text { ным отраслям права } \\
\text { (конституционного, } \\
\text { административного, } \\
\text { гражданского, аграрно- } \\
\text { го, природоресурсного, } \\
\text { трудового, финансово- } \\
\text { го, информационного } \\
\text { и др.) }\end{array}$ & $\begin{array}{l}\text { Введение аграрного } \\
\text { сектора экономики } \\
\text { в качестве приори- } \\
\text { тетной составля- } \\
\text { ющей экономики } \\
\text { страны, где на пер- } \\
\text { вое место выдвига- } \\
\text { ется сельскохозяй- } \\
\text { ственное производ- } \\
\text { ство, подвергаемое } \\
\text { политическому ре- } \\
\text { гулированию., а на } \\
\text { второе место сель- } \\
\text { ская инфраструк- } \\
\text { тура, переработка } \\
\text { сельскохозяйствен- } \\
\text { ной продукции, } \\
\text { обеспечивающая } \\
\text { всемерную под- } \\
\text { держку (материаль- } \\
\text { ную, финансовую, } \\
\text { информационную, } \\
\text { научно-техноло- } \\
\text { гическую и др.), } \\
\text { осуществляемую } \\
\text { посредством оказа- } \\
\text { ния политической } \\
\text { помощи и исполне- } \\
\text { ния политических } \\
\text { воздействий }\end{array}$ & $\begin{array}{l}\text { Структурно упоря- } \\
\text { доченная, полити- } \\
\text { чески одобренная, } \\
\text { юридически за- } \\
\text { крепленная право- } \\
\text { творческая, право- } \\
\text { применительная и } \\
\text { правоохранитель- } \\
\text { ная деятельность, } \\
\text { направленная на } \\
\text { достижение режима } \\
\text { законности в аграр- } \\
\text { ном секторе эконо- } \\
\text { мики }\end{array}$ \\
\hline
\end{tabular}


Государство и гражданское общество

\begin{tabular}{|c|c|c|c|c|c|}
\hline 16. & \begin{tabular}{|l|} 
Социальная \\
природа от- \\
ношений
\end{tabular} & $\begin{array}{l}\text { Отношения, возника- } \\
\text { ющие между взаимо- } \\
\text { действующими лично- } \\
\text { стями и социальными } \\
\text { сообществами в про- } \\
\text { цессе их сознательной } \\
\text { деятельности по пово- } \\
\text { ду устройства и управ- } \\
\text { ления обществом }\end{array}$ & $\begin{array}{l}\text { Совокупность обще- } \\
\text { ственных отношений, } \\
\text { урегулированных пра- } \\
\text { вовыми нормами }\end{array}$ & $\begin{array}{l}\text { Отношения, вос- } \\
\text { производящи- } \\
\text { еся в процессе } \\
\text { формирования и } \\
\text { осуществления } \\
\text { агрохозяйственной } \\
\text { деятельности и по- } \\
\text { литического воздей- } \\
\text { ствия на них }\end{array}$ & $\begin{array}{l}\text { Правоотношения, } \\
\text { являющие формой } \\
\text { реализации норм } \\
\text { аграрного права и } \\
\text { политических уста- } \\
\text { новок государства }\end{array}$ \\
\hline $17 .$. & $\begin{array}{l}\text { Элемент- } \\
\text { ный состав } \\
\text { политиче- } \\
\text { ских отно- } \\
\text { шений }\end{array}$ & $\begin{array}{l}\text { Обладающая присущей } \\
\text { только ей структурой, } \\
\text { атрибутивно обозна- } \\
\text { ченная качественными } \\
\text { свойствами и при- } \\
\text { знаками деятельность } \\
\text { (целями, средствами, } \\
\text { субъектами, предме- } \\
\text { тами) }\end{array}$ & $\begin{array}{l}\text { Норма права, содержа- } \\
\text { ние правоотношения, } \\
\text { юридические факты }\end{array}$ & $\begin{array}{l}\text { Сруктурно обозна- } \\
\text { ченная качествен- } \\
\text { ными свойствами } \\
\text { и признаками } \\
\text { агрохозяйственная } \\
\text { деятельность по } \\
\text { достижению и ро- } \\
\text { сту устойчивости } \\
\text { и эффективности } \\
\text { аграрного и агро- } \\
\text { промышленного } \\
\text { производства, жиз- } \\
\text { ненного уровня } \\
\text { населения, стабиль- } \\
\text { ного развития сель- } \\
\text { ских территорий, } \\
\text { утверждения спра- } \\
\text { ведливого полити- } \\
\text { ческого процесса }\end{array}$ & $\begin{array}{l}\text { Нормы аграрного } \\
\text { права, аграрные } \\
\text { правоотношения, } \\
\text { юридические факты } \\
\text { агроправовой при- } \\
\text { надлежности, поли- } \\
\text { тические правила, } \\
\text { соотносящиеся с } \\
\text { аграрноправовыми } \\
\text { нормами }\end{array}$ \\
\hline 18. & $\begin{array}{l}\text { Содержа- } \\
\text { ние поли- } \\
\text { тики }\end{array}$ & $\begin{array}{l}\text { Деятельность органов } \\
\text { публичной власти по } \\
\text { решению обществен- } \\
\text { ных проблем, регули- } \\
\text { рующему воздействию } \\
\text { на экономику, соци- } \\
\text { альную сферу и другие } \\
\text { объекты посредством } \\
\text { использования ком- } \\
\text { плекса конкретных } \\
\text { правил («правил } \\
\text { игры») и способов их } \\
\text { осуществления. Со- } \\
\text { держание указанной } \\
\text { деятельности пред- } \\
\text { ставляет собой стадий- } \\
\text { но реализуемый цикл, } \\
\text { включающий четыре } \\
\text { этапа: }\end{array}$ & $\begin{array}{l}\text { Деятельность по по- } \\
\text { литическому регули- } \\
\text { рованию в режиме } \\
\text { сочетания институтов } \\
\text { государства и права, } \\
\text { государственного соци- } \\
\text { ального управления и } \\
\text { социальной регламен- } \\
\text { тации, осуществляемая } \\
\text { на основе принципов } \\
\text { правового государства } \\
\text { (верховенство закона, } \\
\text { разделение властей, ре- } \\
\text { альная обеспеченность } \\
\text { прав и свобод граждан, } \\
\text { достижение высокого } \\
\text { уровня политического } \\
\text { и правового сознания, }\end{array}$ & $\begin{array}{l}\text { Экономически } \\
\text { предопределенная } \\
\text { и основанная на } \\
\text { принципах обще- } \\
\text { государственной } \\
\text { социальной поли- } \\
\text { тики, осознанная, } \\
\text { активная деятель- } \\
\text { ность политических } \\
\text { акторов (партий, } \\
\text { союзов, движений } \\
\text { и т.п.), призванная } \\
\text { обеспечивать разви- } \\
\text { тие аграрной сфе- } \\
\text { ры производства, } \\
\text { опираясь на власть, } \\
\text { принуждение, по- } \\
\text { зитивную }\end{array}$ & $\begin{array}{l}\text { Деятельность по } \\
\text { юридическому за- } \\
\text { креплению и пре- } \\
\text { творению в жизнь } \\
\text { предпринимаемых } \\
\text { государством мер } \\
\text { воздействия на } \\
\text { агро-экономические } \\
\text { процессы, аграрно- } \\
\text { правовое обеспе- } \\
\text { чение достижения } \\
\text { устойчивости и } \\
\text { эффективности } \\
\text { производства, улуч- } \\
\text { шение макро- и } \\
\text { микроэкономиче- } \\
\text { ских показателей } \\
\text { хозяйствования, }\end{array}$ \\
\hline
\end{tabular}




\section{Политика и общество $3(99) \cdot 2013$}

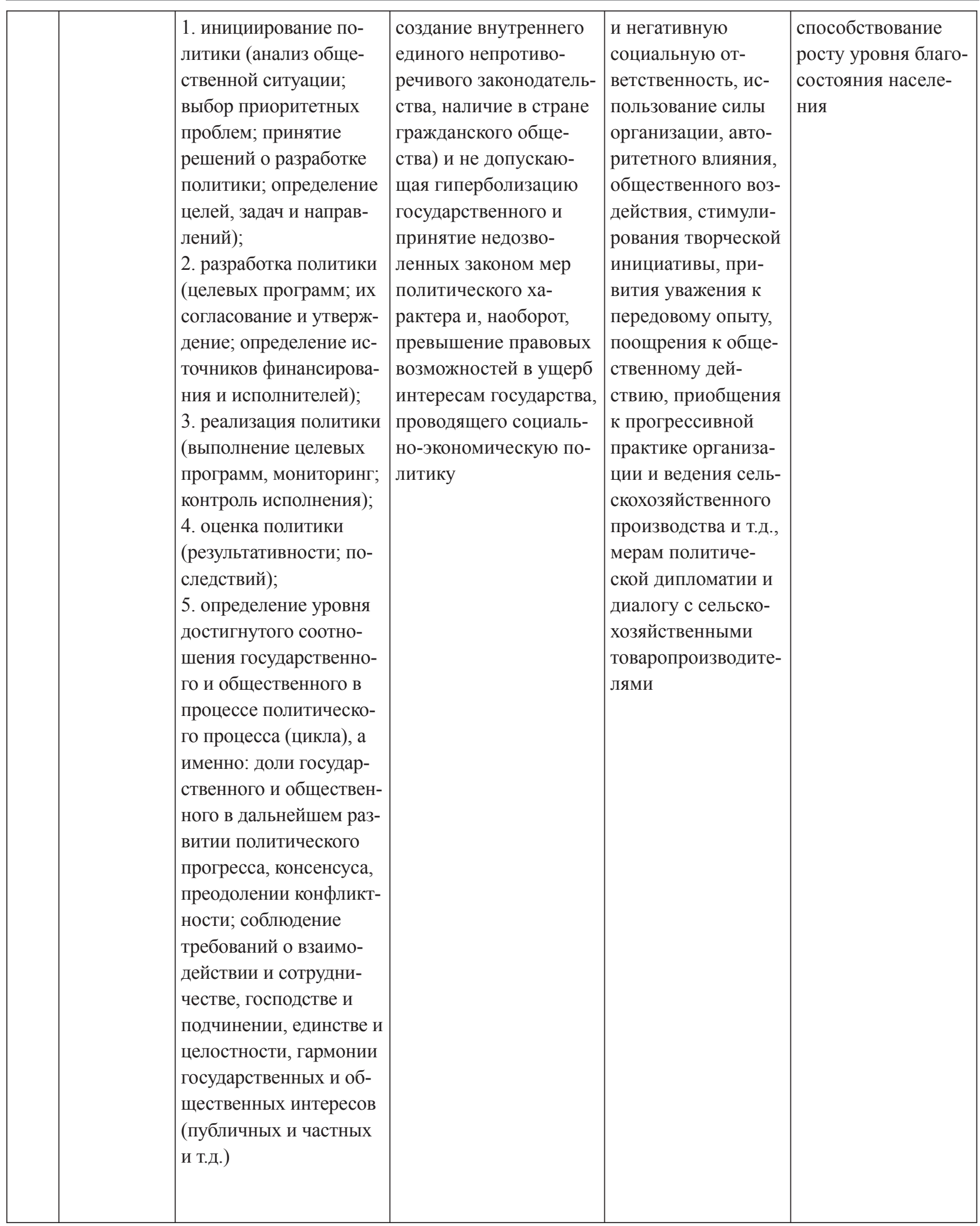


Государство и гражданское общество

\begin{tabular}{|c|c|c|c|c|c|}
\hline 19. & $\begin{array}{l}\text { Результа- } \\
\text { тивность } \\
\text { политики }\end{array}$ & $\begin{array}{l}\text { Специально утвержден- } \\
\text { ных показателей полити- } \\
\text { ческого развития страны } \\
\text { не имеется. Обычно ут- } \\
\text { верждается, что действую- } \\
\text { щая общегосударственная } \\
\text { политика выдержала } \\
\text { испытание временем, что } \\
\text { свидетельствует о торже- } \\
\text { стве практики хозяйство- } \\
\text { вания, экономического } \\
\text { и политического бытия } \\
\text { и идеологии социально- } \\
\text { экономического развития. } \\
\text { Вклад политического вли- } \\
\text { яния в результаты устой- } \\
\text { чивого и эффективного } \\
\text { развития экономики и со- } \\
\text { циальной сферы государ- } \\
\text { ства и общества косвенно } \\
\text { подтверждается восприя- } \\
\text { тием его в составе макроэ- } \\
\text { кономических показателей } \\
\text { экономического роста и } \\
\text { социального обеспечения } \\
\text { (ВВП, темпы экономи- } \\
\text { ческого роста, индексы } \\
\text { производства продукции, } \\
\text { средний уровень зарплаты } \\
\text { на душу населения и др.) }\end{array}$ & $\begin{array}{l}\text { Снижение уровня пре- } \\
\text { ступности и правона- } \\
\text { рушений, достигнутое } \\
\text { под воздействием } \\
\text { проведения политики } \\
\text { неприятия криминаль- } \\
\text { ного и деликтного } \\
\text { поведения, борьба с } \\
\text { коррупцией, создание } \\
\text { обстановки нетерпи- } \\
\text { мости к нарушениям } \\
\text { законов и основанных } \\
\text { на них актов, проведе- } \\
\text { ние в жизнь принципа } \\
\text { неотвратимости ответ- } \\
\text { ственности }\end{array}$ & $\begin{array}{l}\text { Политически } \\
\text { предопределен- } \\
\text { ная (признанная, } \\
\text { одобренная) и } \\
\text { доктринально, } \\
\text { стратегически и } \\
\text { концептуально вер- } \\
\text { но и рационально } \\
\text { осуществленная } \\
\text { агрохозяйственная } \\
\text { и социальная дея- } \\
\text { тельность, завер- } \\
\text { шающаяся преодо- } \\
\text { лением отсталости } \\
\text { отрасли, достиже- } \\
\text { нием устойчивости } \\
\text { и эффективности } \\
\text { сельского хозяйства } \\
\text { и АПК (ростом обь- } \\
\text { емов производства } \\
\text { сельскохозяйствен- } \\
\text { ной продукции, } \\
\text { урожайности куль- } \\
\text { тур, повышением } \\
\text { продуктивности } \\
\text { животных и птиц, } \\
\text { уровня импортоза- } \\
\text { мещения и др.) }\end{array}$ & $\begin{array}{l}\text { Надлежаще ор- } \\
\text { ганизованная и } \\
\text { политически под- } \\
\text { держанная система } \\
\text { аграрно-правового } \\
\text { обеспечения сель- } \\
\text { скохозяйственного } \\
\text { производства, со- } \\
\text { провождающаяся } \\
\text { улучшением всех } \\
\text { показателей раз- } \\
\text { вития отрасли, } \\
\text { ее подотраслей, } \\
\text { направлений хо- } \\
\text { зяйствования, } \\
\text { воспроизводства } \\
\text { продукции, соблю- } \\
\text { дения технологиче- } \\
\text { ской дисциплины, } \\
\text { режима социальной } \\
\text { и правовой ответ- } \\
\text { ственности }\end{array}$ \\
\hline 20. & $\begin{array}{l}\text { Инстру- } \\
\text { менты ста- } \\
\text { новления и } \\
\text { бытия }\end{array}$ & $\begin{array}{l}\text { Демократическое } \\
\text { государство, граждан- } \\
\text { ское общество и их } \\
\text { социальные институ- } \\
\text { ты (установления - } \\
\text { INSTITUTUM) }\end{array}$ & $\begin{array}{l}\text { Правовое государство, } \\
\text { гражданское общество } \\
\text { и их институты }\end{array}$ & $\begin{array}{l}\text { Социальное госу- } \\
\text { дарство, гаранти- } \\
\text { рующее создание } \\
\text { условий, обеспечи- } \\
\text { вающих достойную } \\
\text { жизнь и свободное } \\
\text { развитие человека. } \\
\text { Аграрная экономи- } \\
\text { ка и ее социальные } \\
\text { институты, а также } \\
\text { соответствующие } \\
\text { им политические } \\
\text { механизмы воздей- } \\
\text { ствия на аграрные } \\
\text { отношения }\end{array}$ & $\begin{array}{l}\text { Совокупность аграр- } \\
\text { но-правовых норм, } \\
\text { регулирующих агро- } \\
\text { хозяйственные отно- } \\
\text { шения, являющихся } \\
\text { основаниями государ- } \\
\text { ственного политиче- } \\
\text { ского воздействия на } \\
\text { них, гармонизации } \\
\text { правового и полити- } \\
\text { ческого влияния на } \\
\text { развитие агропрома, } \\
\text { принятие решений в } \\
\text { условиях объектив- } \\
\text { ных, природных из- } \\
\text { менчивых факторов и } \\
\text { поступков (действий) } \\
\text { сельских товаропро- } \\
\text { изводителей }\end{array}$ \\
\hline
\end{tabular}


Политика и общество 3 (99) • 2013

\begin{tabular}{|c|c|c|c|c|c|}
\hline 21. & $\begin{array}{l}\text { Легити- } \\
\text { мация по- } \\
\text { литической } \\
\text { власти }\end{array}$ & $\begin{array}{l}\text { Реальная политическая } \\
\text { деятельность, соот- } \\
\text { ветствующая офици- } \\
\text { альным политическим } \\
\text { нормам, установлен- } \\
\text { ным во множестве } \\
\text { документов типа ре- } \\
\text { шений сьездов партий, } \\
\text { принятых на их основе } \\
\text { постановлений прави- } \\
\text { тельств, министерств } \\
\text { и других органов госу- } \\
\text { дарственной власти и } \\
\text { управления, основных } \\
\text { направлений социаль- } \\
\text { но-экономического } \\
\text { развития страны, кон- } \\
\text { трольных цифр и т.д., } \\
\text { носящих доминантно- } \\
\text { догматический, факти- } \\
\text { чески декларативный } \\
\text { характер }\end{array}$ & $\begin{array}{l}\text { Осуществление по- } \\
\text { литической власти в } \\
\text { режиме декларатив- } \\
\text { ной, и законодательно } \\
\text { определенной, заранее } \\
\text { известной участникам } \\
\text { политической системы, } \\
\text { неисполнимости }\end{array}$ & $\begin{array}{l}\text { Аграрно-политиче- } \\
\text { ская деятельность } \\
\text { в аграрном секторе } \\
\text { экономики осу- } \\
\text { ществлялась в соот- } \\
\text { ветствии с полити- } \\
\text { кой, догматически } \\
\text { обусловленной и } \\
\text { ставшей общего- } \\
\text { сударственной, иг- } \\
\text { норирующей зако- } \\
\text { номерности закона } \\
\text { природы }\end{array}$ & $\begin{array}{l}\text { Аграрно-правовые } \\
\text { нормы отрасли, от- } \\
\text { ражающие сложив- } \\
\text { шееся состояние } \\
\text { аграрной эконо- } \\
\text { мики, стоящие на } \\
\text { страже порядков, } \\
\text { закрепляющих от- } \\
\text { сталость, необосно- } \\
\text { ванную реформи- } \\
\text { руемость сельского } \\
\text { хозяйства и АПК, } \\
\text { спровоцировав- } \\
\text { шее банкротство и } \\
\text { тотальный развал } \\
\text { аграрной экономи- } \\
\text { ки, выдвинувшие } \\
\text { проблему развития } \\
\text { и реализации новой } \\
\text { аграрной поли- } \\
\text { тики государства } \\
\text { - Государственной } \\
\text { аграрной политики } \\
\text { России в качестве } \\
\text { особого норматив- } \\
\text { ного акта }\end{array}$ \\
\hline
\end{tabular}

Предпринятый нами анализ свидетельствует, что аграрной политике присущи все признаки и свойства государственной политики, так как в ней присутствует весь комплекс элементов, характерных для последней (обусловленность объективным фактором - всеобщим законом саморегуляции природы и его закономерностями, а также субъективным фактором - концептуально осмысленным восприятием). Предпосылками ее становления и бытия являются эти же обстоятельства. Генератором (GENERATOR - родитель) аграрной экономики и инициатором аграрной политики, превращающими их в действительность (IN NATURA), в обязательное составляющее мироздания (IN LEAST), воспроизводящими, возводящими экономику и политику в некое целостное экономико-социальное образование (RESTITUTIO IN INTEGRUM), в самостоятельное и сущностное, существенное (SUBSTANTIA), выступают именно указанные качества обозначенных факторов.

Однако здесь уместны некоторые замечания. Следует отметить, что учет факторальных данных должен отражать особенности аграрной экономи- ки и аграрной политики (DIFFERENTIA SRECIFICA). В частности, политическое воздействие на аграрный сектор экономики должно базироваться на признании особой природы агрохозяйственной деятельности, ее биологической обусловленности, зависимости от биоклиматических факторов, отражении разноуровневых и многопрофильных сигналов в реальных условиях становления и бытия, прежде всего, естественных изменчивых факторов, называемых событиями (не зависящими от воли и усмотрения участников аграрных отношений), а также действий - поступков этих участников. Подобное воздействие мыслимо лишь при выдвижении особых же целей и задач, реализации их в присущих только агрополитическому воздействию формах пространственно-временного осуществления, в заранее предопределенной экономической и социально детерминированной среде агропроизводственной деятельности, не совпадающих с обычными представлениями о пространстве и времени. Агрополитическое пространство охватывает лишь то географическое и экономическое, что обусловлено 
Государство и гражданское общество

общественным разделением труда, специализацией и размещением сельскохозяйственного производства, его инфраструктуры, потребностями сельского развития. И агрополитическое время есть не столько мера физического времени, сколько многомерное явление реальной действительности, содержание и пределы которого определяются характером, длительностью, последовательностью взаимодействия субъектов аграрного производства и субъектов, так или иначе причастных к нему. Точно также сфера бытия аграрной политики включает не только область отношений по политическому воздействию на аграрное и агропромышленное производство, но и область совместного влияния и регулирования, политического и правового регламентирования.

Аграрная политика государства должна исходить из осознания того неоспоримого факта, что сельское хозяйство и АПК являются ведущими и ничем не заменимыми составляющими российской экономики. Они оказывают «решающее влияние на уровень производственного обеспечения и благосостояния народа, в значительной мере определяют состояние всей экономики страны ${ }^{2}$. По этой причине она достойна приоритетного внимания со стороны государства и гражданского общества, что достаточно рельефно отражено в приведенной таблице.

Наконец, совокупность признаков и свойств, подвергнутых специальному исследованию и зафиксированных в таблице, свидетельствуют о системности, структурности всего спектра агрополитических отношений России, который представляет собой социальную общность связей, и, как следствие этого, обладает относительной самостоятельностью в рамках общегосударственной политики, легитимируемой в виде Государственной аграрной политики Российской Федерации.

Государственная аграрная политика призвана отражать структурные свойства агрохозяйственной деятельности как социального образования, включающего огромное множество взаимосвязанных отношений и соответствующих их содержанию предложений. Она способна возвести такое множество к общему, многого к единому пониманию внутреннего родства аграрного производства, аграрной экономики, открывает путь к обоснова- нию эмпирических агрохозяйственных мероприятий, создает почву для социального познания, позитивного подхода к возможным и существующим ценностям, к сознательному опредмечиванию человеческого поведения в действие, приданию ему субъективно концептуального смысла, разрешению дилеммы объективного и субъективного , взаимно обусловленной объективации и объективирования утверждению регулятивных принципов (PRINCIPIUM - основа, первоначало) естествознания(наблюдаемости, соответствия, эмпирической проверяемости, инвариантности, ограничений, дозволенности, объективной доступности выбора хозяйственной системы и других приоритетов (побудительных, повелительных мотивов) триумфа (TRIUMPHUS - блестящий успех), преодоления отсталости (социального события) отрасли и ее подотраслей, сельского хозяйства и АПК страны, достижения их прогрессивного развития.

\section{Библиография:}

1. Ханнанов Р.А., Ханнанова Т.Р. События в системе правового обеспечения модернизации социально-экономического развития России: теория и практика [Текст] - Уфа.: Башкирский ГАУ, АН РБ, 2012. - 162 с. - С. 17-35, 65-95, 97-106.

2. Никляев В.С., Ткачев В.В., Сучилин А.А. Основы технологии сельскохозяйственного производства. Земледелие и растениеводство [Текст] - М.: Былина, 2000. -555 с. - С. 3.

\section{References (transliteration):}

1. Khannanov R.A., Khannanova T.R. Sobytiya v sisteme pravovogo obespecheniya modernizatsii sotsial'no-ekonomicheskogo razvitiya Rossii: teoriya i praktika [Tekst] - Ufa.: Bashkirskiy GAU, AN RB, 2012. - 162 s. - S. 17-35, 65-95, 97-106.

2. Niklyaev V.S., Tkachev V.V., Suchilin A.A. Osnovy tekhnologii sel'skokhozyaystvennogo proizvodstva. Zemledelie i rastenievodstvo [Tekst] - M.: Bylina, 2000. -555 s. - S. 3.

\footnotetext{
${ }^{2}$ Никляев В.С., Ткачев В.В., Сучилин А.А. Основы технологии сельскохозяйственного производства. Земледелие и растениеводство. - М.: Былина, 2000. - 555 с. - С. 3.
} 